\title{
Developing Intercultural Language Learning (ILL) model to teach writing skills at Indonesian private universities
}

\author{
${ }^{1}$ Haerazi $^{*},{ }^{1}$ Lalu Ari Irawan \\ English Language Education Graduate Program, Universitas Pendidikan Mandalika, \\ Indonesia \\ *Corresponding Author \\ Email: haerazi@ikipmataram.ac.id
}

\begin{abstract}
This study was aimed at developing an intercultural language learning (ILL) model and finding out its effectiveness to increase students' writing skills. The kind of this study was procedural research $(R \& D)$ design. This study was preceded with the development phases and continued by field-testing. The field-testing was conducted by using a quasi-experimental method to know the effectiveness of the developed learning model. The sample included 64 students. The students were divided into two groups and each group consisted of 32 students. One group was the experimental group taught by suing the ILL model and the other group was the control group taught by implementing the conventional learning model. The mean score of students taught by ILL model was 80.34 and those taught by conventional one was 69.97. The data were defined as normal and homogeneous data because the value of sig. was higher than sig. level 0.05. Based on the ANOVA test, the value of sig. $(0,000)$ was lower than the sig. level 0.05. It means there is a significantly different achievement of students taught using an ILL model rather than the conventional learning model. The result informed ILL model was more effective than the conventional one in the teaching of writing skills.
\end{abstract}

Keywords: Intercultural language learning; writing skills

Received:

Revised:

Accepted:

Published:

25 September 201928 January 2020

3 February 2020

29 February 2020

\section{INTRODUCTION}

In recent years English teachers have been paying increasing attention to intercultural language learning to get intercultural competences (Dimitrov, Dawson, Olsen, \& Meadows, 2014). The intercultural competences are assumed that those give opportunities for learners to get linguistics knowledge and cultural aspects of English natives. The linguistic knowledge and cultural aspects are acquired when teachers present language instructional materials containing cultural aspects. Researches concentrating on the intercultural language learning have been conducted by some researchers such as Liddicoat (2013), Liddicoat \& Scarino (2013), Zhu (2010, 107), Sun (2013, 371-375), Xue (2014, 1493), and Yu et al. (2014, 38-46).

Writing in EFL for many Asian students such as Indonesia, Thailand, Japan, Korean and another Asian country was difficult activities in practice 
Haerazi, \& Irawan, L.A. (2020). Developing Intercultural Language Learning (ILL) model to teach writing skills at Indonesian private universities. EduLite: Journal of English Education, Literature, and Culture, 5 (1), 43-54. DOI: http://dx.doi.org/10.30659/e.5.1. 43-54

(Hasani, 2016, Suriyanti \& Yaacob, 2016). Asian students faced obstacles to write English texts because of lack of English structural knowledge (Hoti, 2014), insufficient dictions, limited vocabularies (Nurjanah, et al. (2019), and cultures (Lee et al., 2017; Lee, 2016; Alessio \& Riley, 2002). In the context of teaching writing, Myhill \& Watson (in Green, 2011) theorize the teaching of writing into three disciplinary approaches; cognitive psychology, linguistics, and sociocultural approach. Students have to arrange their mental process when they are writing; they must manage the language accurately to create texts, and they write within a social context that affects how they see and value the texts they write. Therefore, writing in EFL appears to be an excruciating activity and it needs an appropriate instructional model as a solution.

The ability to write a foreign language fluently and accurately presupposes not only a good knowledge of language features but also the ability to process issues based on English native cultures. Richard \& Renandya (2002) state "whenever you teach a language, you teach a complex system of cultural customs, values, and ways of thinking, feeling, and acting". That is why non-native English teachers have been increasingly aware that the English language can be learned hardly without addressing the cultural aspects reflected in the English language in which it is spoken (Kanp \& Watkin, 2005; and Biebricher, et al. (2019). The culture of the community determines how the language itself to be expressed to others. Besides, Hadi and Andrian (2018) recommended the local curriculum in maintaining the local wisdom with local cultural values.

In teaching English as a foreign language for writing skills, linguistic knowledge alone is not enough in guaranteeing successful writing (Atay et al. 2009). Cultural mistakes are worse than linguistic ones because they tend to create misunderstanding between English natives and non-natives. Cultural aspects are necessary to be learned by students to avoid misjudgments or ill feelings. For this reason, English teachers should devote English instructional materials containing cultural aspects for their students in writing classrooms although writing anxiety is needed to be paid attention (Berk, 2017).

In Indonesia, English is regarded as a foreign language and is largely treated as an academic subject in the school and is not widely used outside of the classroom. In the Indonesian curriculum, writing knowledge and skills are embedded in the course subject of English and Indonesia, each with two credit hours (Sinaga \& Feranie, 2017). Therefore, students face difficulties in performing English in writing (Haerazi \& Irawan, 2019). The students are required to master linguistic competences and even sociocultural-competences (Murcia, 2007). Therefore, acts of writing need various processes for students to be a good writer. What Indonesian students faced was as same as students in the western countries. Also, Farahian (2017) suggested the knowledge of cognition and regulation of cognition also is inserted for students to be acquired in the writing class.

Sharp (2016) in his research found that teachers of writing potentially lack an understanding into the various processes at work during the acts of writing among each student writer. This process would be that the writing instruction potentially was narrow, rigid, and inflexible. Non-native teachers and even native English teachers face difficulties in acts of writing because 
writing is a developmental and flexible process. Language learners from different cultures have their own cultural beliefs, values and social customs that strongly determine the communication way orally and in written (Zhang, 2010). In his research in China, he dwells on the four dimensional-approach to develop students' intercultural competences, i.e. teaching students' basic knowledge of western culture in class and providing more teaching practice chances for all kinds of activities in class.

The teaching of writing skills based on intercultural learning is proposed to stimulate and increase students' writing skills through developing intercultural competences. The development of intercultural competences helps students to increase their ideas and thoughts (Byram, 2007; Byram et al., 2002; Aprianoto \& Haerazi, 2019). To gain intercultural competences, teachers need to develop a particular instructional model oriented to intercultural language learning. Intercultural competences are assumed to be closely integrated with learning to know, learning to do, and learning to be (UNESCO, 2013).

Based on the consideration above, this research was aimed at developing an intercultural language learning (ILL) model for teaching writing skills. The contributions of this article to literature include the intercultural language learning model that can be utilized to teach English students in writing classrooms. Writing is often considered a difficult skill to be mastered by foreign students and events for the native speakers. Intercultural competences, the capability to express ideas in paragraphs that are linguistically acceptable and culturally appropriate, are increasingly recognized as a key of the $21^{\text {st }}$ century learning competence. Therefore, this study was focused on developing intercultural language learning. The novelty of this study lies in the utilization of students' own cultures and the target cultures to develop language awareness. At the end of this, students can apply their linguistic knowledge to write. Particularly, the purpose of this study is to design and validate the intercultural language learning (ILL) model for the English language department in private universities in West Nusa Tenggara, Indonesia.

\section{METHOD}

\section{Research design}

The study was a research and development (R\&D) design that has three stages: (1) need analysis, (2) designing the learning model based on the results of needs analysis, and (3) field testing of the model. To know the effectiveness of the ILL model, the quasi-experimental method was applied. The population of this study included the fifth semesters of the English language department which consisted of 128 students. It was distributed in four classes. The students of the class VA and VB were chosen as samples of this study. Two groups were taught by different teaching models. One group was called the experimental group taught by using the developed learning model for writing and the other group was subjected to a conventional teaching model, as the control group. Each group consisted of 32 students. The total sample was 64 students of English language education students. At the end of treatments, 
Haerazi, \& Irawan, L.A. (2020). Developing Intercultural Language Learning (ILL) model to teach writing skills at Indonesian private universities. EduLite: Journal of English Education, Literature, and Culture, 5 (1), 43-54. DOI: http://dx.doi.org/10.30659/e.5.1. 43-54

the students' achievement of both groups was compared to find out the different learning achievement.

\section{Research setting}

This study was conducted in private universities at West Nusa Tengara, namely IKIP Mataram, Muhammadiyah University, Nahdlatul Wathan University, and Hamzanwadi University. These universities have been qualified ELT institutions to be considered as the research setting. The data were taken in the four educational institutions but the product was tried out at IKIP Mataram. It was chosen as the field-testing because the study program of English education holds the B accreditation from Higher education Body Accreditation in Indonesia. In addition, the instructional facilities for supporting this study are more available than the three private universities. Therefore, the implementation of the developed model was done in the English language department of IKIP Mataram. This study was held from November 2018-January 2019.

\section{Research instruments}

The instruments of this study include questionnaires, observations, interviews, and writing tests. The data of needs analysis about students' learning needs and target needs were collected by questionnaires. Meanwhile, the data of the quality on the developed learning model, ILL model, were obtained from observations, interviews, and students' achievement. There were two kinds of data which are qualitative and quantitative data. The qualitative data provided information about students' needs (target and learning needs) and the result of interviews. Meanwhile, the quantitative data indicated information about students' writing achievement.

\section{Data analysis technique}

This study was analyzed by mix-method design. It was conducted by qualitative and quantitative data analyzed as well as combined data (Sugiyono, 2011). The data of needs analysis were analyzed descriptively. The results were a description of the students' needs based on the target and learning needs in writing classrooms and students' responses toward the developed learning model. The data from the interview were analyzed qualitatively by conducting recording and then transcribing. The interview was done to strengthen the data obtained from the needs analysis. Meanwhile, the data of students' writing skills were computed quantitatively to know the effect of the ILL model on students' achievement.

The quantitative test was conducted statistically using analysis of variance (ANOVA) to know the effect of the ILL model. The statistical program of IBM SPSS 21.0 was employed. The normality and homogeneity data were analyzed. The data decided normal data because the sig. value (0.144) and $(0.781)$ was higher than sig. level 0.05 for both groups, the experimental and control group respectively. To know this, the researcher used the KolmogorovSmirnov formula. Meanwhile, the data concluded homogenous data because the value of sig. (0.696) was higher than the significant level of 0.05. In doing so, Levene test was employed in this study. 


\section{RESULTS AND DISCUSSION}

The intercultural language learning model for writing skills has been developed in line with the students' needs (target needs and learning needs) at some private universities and it was field-testing at IKIP Mataram in the fourth-semester students.

Table 2. The developed instructional model for writing skills

\begin{tabular}{|c|c|c|}
\hline No & Phase & Learning Activities \\
\hline 1 & $\begin{array}{l}\text { Phase } 1 \\
\text { Noticing }\end{array}$ & $\begin{array}{l}\text { Students are given a touch of cultural dimensions of the topics and a } \\
\text { practice in writing individual sentences. } \\
\text { Students are subjected to notice different aspects of their culture and } \\
\text { those of the target cultures. } \\
\text { Students are directed to write the aspects of cultures in individual } \\
\text { sentence related to the topic sentence. } \\
\text { At the end of this phase, students are expected to create sentences } \\
\text { going to be utilized as topic sentences in the next phases. }\end{array}$ \\
\hline 2 & $\begin{array}{l}\text { Phase } 2 \\
\text { Comparing }\end{array}$ & $\begin{array}{l}\text { Students are asked to compare the various aspects of the cultural } \\
\text { objects being discussed on the basis on activities that they have } \\
\text { conducted in the noticing phase. } \\
\text { Students produce sentences based on inputs of the result of the } \\
\text { comparison and it is used as supporting details in paragraphs. } \\
\text { Students are directed to associate features of their own cultures and } \\
\text { those of the target cultures in line with the topic sentence provided. } \\
\text { At the end of this phase, students are expected to produce a number } \\
\text { of sentences that are later employed as supporting details in } \\
\text { paragraphs. }\end{array}$ \\
\hline 3 & $\begin{array}{l}\text { Phase } 3 \\
\text { Reflecting }\end{array}$ & $\begin{array}{l}\text { Students reflect their understanding of experiences after comparing } \\
\text { their own cultures and the target culture. } \\
\text { Students are directed to appreciate the diversities of cultural values } \\
\text { as input to create paragraphs. } \\
\text { - Students are given clues in the form of individual sentences to create } \\
\text { reflective sentences or paragraphs. } \\
\text { - Students are provided with exercises such as jumbled paragraphs. } \\
\text { At the end of this phase, students produce a number of sentences } \\
\text { that are later used as supporting details in paragraphs. }\end{array}$ \\
\hline 4 & $\begin{array}{l}\text { Phase } 4 \\
\text { Constructing }\end{array}$ & $\begin{array}{l}\text { Students construct their ideas and intercultural experiences that } \\
\text { they have carried out in reflecting phase in forms of complete } \\
\text { paragraphs. } \\
\text { Given a graphic organizer, students are asked to construct the } \\
\text { complete paragraph dealing with the topic sentence provided. } \\
\text { In a small group, students cooperate by elaborating their knowledge } \\
\text { and skills in composing paragraphs. } \\
\text { At the end of this phase, students are able to produce a complete } \\
\text { text. }\end{array}$ \\
\hline 5 & $\begin{array}{l}\text { Phase } 5 \\
\text { Presenting }\end{array}$ & $\begin{array}{l}\text { Students present the complete text in front of the class. } \\
\circ \text { Students are directed to elaborate and explore their intercultural } \\
\text { understanding and experiences of cultural diversities in the class. } \\
\circ \text { In groups, students cooperate by giving their ideas and skills in } \\
\text { presenting the complete text. } \\
\circ \text { The other groups give comments and suggestion towards the text }\end{array}$ \\
\hline
\end{tabular}


Haerazi, \& Irawan, L.A. (2020). Developing Intercultural Language Learning (ILL) model to teach writing skills at Indonesian private universities. EduLite: Journal of English Education, Literature, and Culture, 5 (1), 43-54. DOI: http://dx.doi.org/10.30659/e.5.1. 43-54

resulted on the basis on the organization, content, vocabulary, language, and mechanic of the text.

After the learning model was designed, the model was tried out. The experimental research was involved 2 lecturers per university, so totally there were 8 lecturers who involved in experimenting ILL model in the teaching of writing skills. 6 lecturers involved in developing the learning activities and raters and 2 lecturers participated as lecturers to teach writing skills. Thus, the sample groups came from the population in the normal distribution. The statistical analysis is presented in Table 3.

Table 3. The result of students' writing scores

\begin{tabular}{|c|c|c|c|c|c|c|}
\hline \multirow[t]{2}{*}{ Classes } & \multirow[t]{2}{*}{$\mathrm{N}$} & \multirow[t]{2}{*}{ Mean } & \multirow{2}{*}{$\begin{array}{c}\text { Std. } \\
\text { Deviation }\end{array}$} & \multirow{2}{*}{$\begin{array}{l}\text { Std. } \\
\text { Error }\end{array}$} & \multicolumn{2}{|c|}{$\begin{array}{l}\text { 95\% Confidence } \\
\text { Interval for Mean }\end{array}$} \\
\hline & & & & & Lower Bound & Upper Bound \\
\hline Experimental Class & 32 & 80.34 & 6.131 & 1.084 & 78.13 & 82.55 \\
\hline Control Class & 32 & 69.97 & 5.480 & .969 & 67.99 & 71.94 \\
\hline Total & 64 & 75.16 & 7.785 & .973 & 73.21 & 77.10 \\
\hline
\end{tabular}

The mean score of students in both groups was assessed by six lecturers. The inter-raters' score was no different score variance. Table 3 informed the mean score of students who were taught by using the ILL model was 80.34 and the mean score of students who were subjected to conventional one was 69.97. Each student consisted of 32 students and they were provided for different instructional treatments. Afterward, the researchers focused on the lecturers' perception of dealing with the developed model aspects. The lecturers were asked to give their opinion in relation to the teaching steps of the ILL model, classroom atmosphere, time allocation, students' writing activities, lecturers' performance, teaching materials, and students' interest of the model. The complete data of those can be seen on Table 4 as follows.

Table 4. The result of questionnaire on lecturer's perception

\begin{tabular}{|c|c|c|c|c|c|}
\hline \multirow{2}{*}{ No } & \multirow{2}{*}{ Aspect Assessed } & \multicolumn{2}{|c|}{$\begin{array}{c}\text { Lecturers' } \\
\text { Perception }\end{array}$} & \multicolumn{2}{|c|}{ Percentage } \\
\hline & & Like & Dislike & Like & Dislike \\
\hline 1 & Teaching Steps of ILL model are easy to apply. & 8 & 0 & 100 & 0 \\
\hline 2 & $\begin{array}{l}\text { Classroom Situation of ILL model is } \\
\text { appropriate to facilitate students to write. }\end{array}$ & 8 & 0 & 100 & 0 \\
\hline 3 & $\begin{array}{l}\text { Time Allocation can be organized with the ILL } \\
\text { materials provided. }\end{array}$ & 8 & 0 & 100 & 0 \\
\hline 4 & $\begin{array}{l}\text { Writing Activities are effective to write in ILL } \\
\text { class. }\end{array}$ & 8 & 0 & 100 & 0 \\
\hline 5 & $\begin{array}{l}\text { Lecturer's Performance looks easy to deliver } \\
\text { the writing tasks. }\end{array}$ & 7 & 1 & 80 & 20 \\
\hline 6 & $\begin{array}{l}\text { Teaching Materials are useful for students to } \\
\text { practice writing. }\end{array}$ & 8 & 0 & 100 & 0 \\
\hline \multirow[t]{2}{*}{7} & $\begin{array}{l}\text { You have an interest or will to apply the model } \\
\text { in your classes. }\end{array}$ & 8 & 0 & 100 & 0 \\
\hline & Mean (\%) & & & 91 & 9 \\
\hline
\end{tabular}


There were 8 lecturers of writing involved in this study. They were asked to give their opinions or perceptions dealing with the developed learning model. The seven aspects assessed represented the aspect of the learning-teaching process. It was aimed at finding out the feedback of the lecturers after practicing the ILL model in the classes in the form of the experimental treatment. The aspects of the model, such as the steps of teaching, classroom management, time-allocation, learning activities, lecturers' performance, teaching materials, and students' interest, should be comfortable with lecturers' condition and expectation. Most lecturers informed that the developed model was appropriate for facilitating students to practice writing.

Table 5. The result of ANOVA test

\begin{tabular}{lcrrrr}
\hline \multicolumn{1}{c}{ Score } & $\begin{array}{c}\text { Sum of } \\
\text { Squares }\end{array}$ & df & $\begin{array}{c}\text { Mean } \\
\text { Square }\end{array}$ & F & Sig. \\
\hline Between Groups & 1722.250 & 1 & 1722.250 & 50.940 & .000 \\
\hline Within Groups & 2096.188 & 62 & 33.809 & & \\
\hline Total & 3818.438 & 63 & & & \\
\hline
\end{tabular}

Developing language students' competences to communicate effectively in written or spoken forms has come to be viewed as adequate to prepare language students to express their ideas effectively from the target culture. Based on the analysis of statistical data, the mean score of students who were taught by using the ILL model was 80.34 , whereas the mean score of students taught by applying the conventional learning model was 69.97. It depicted that the mean score of students in the experimental class was higher than those in the control class. In other words, the ILL model was able to improve students' writing skills for the fourth-semester students of the English language education study program. It was in line with what Biebricher et al. (2019) conducted in their research that intercultural language instruction helps language learners to improve their linguistic competences by exposing intercultural topics.

Based on the ANOVA test, the value of sig. (0.000) was lower than the sig. level 0.05. It informed the ILL learning model had significant differences in teaching writing skills for the fourth-semester students of English language education study program at IKIP Mataram. ILL model is more practice than the traditional learning model to facilitate students to practice writing. This study showed that students taught by applying the ILL model had significantly different achievements rather than the conventional learning model in the teaching of writing skills for fourth-semester students. This finding was in line with Pu and Evan's (2018) finding that in the context of cross-cultures students are able to demonstrate their language abilities and their positioning skills.

In this study, the research finding informed that students were able to develop their writing skills. In the learning process, students are asked to determine the cultural topics they want to write. Before doing so, they label the cultural features in the form of pictures, videos, and texts. It was in accordance with what Biebricher et al. (2019), Lourenco et al. (2017), and Pu 
Haerazi, \& Irawan, L.A. (2020). Developing Intercultural Language Learning (ILL) model to teach writing skills at Indonesian private universities. EduLite: Journal of English Education, Literature, and Culture, 5 (1), 43-54. DOI: http://dx.doi.org/10.30659/e.5.1. 43-54

\& Evan's (2018) finding that cultural topics are functioned to increase students' language awareness. Inline with this aim, the researchers provide for students with intercultural topics in the form of pictures, texts, and videos. Meanwhile, in the small group students discuss the values of their own cultures and the target cultures provided by teachers. The discussion to notice cultural features occurs during 10-15 minutes. At the end of this process, students are able to produce topic sentences that are developed as sentences in the next phase of the ILL model.

The writing activities in the noticing step bring students to acquire comprehensive information dealing with the target cultures and their own cultures. These activities directed students to internalize their own cultures. The result of the internalization process was used to compare their own cultural aspects with the target cultural aspects. In this situation, students acquire new various vocabularies and phrases to express cultural values. According to Dimitrijevic (2019), vocabulary mastery affected intercultural abilities. Therefore, the implementation of the ILL model helps students diminish intercultural problems in performing their ideas in the texts. The results of these learning activities would become students' input for conducting the next teaching step of the ILL model, which is the comparing step.

In the stage of comparing, students are asked to compare the cultural aspects of their own cultures and those of the target cultures in line with the topic sentences in the previous stage. Students are given more chances to discuss those aspects in order that they can capture all aspects of their own cultures and those of the target cultures. It was compatible with what Haerazi et al. (2018) conducted in their research that students through discussion build their perception of their own cultures. They internalize the values of those and give interpretation about those in sentences. It was also conducted by Aprianoto, et al. (2018) in speaking classes in which students were involved to do interpretation about their perception in texts before doing communication session. Afterwards they continue giving a perception of those of the target cultures. In this process, they are also requested to note the linguistic features used to label the cultural features. At the end of this process, they are able to create several sentences that are used as supporting details.

In the two phases above, lecturers paid attention to students' learning activities in determining the topic sentence, making sentences, and producing supporting sentences. The classroom activities look active situations because students involve in the learning process. Students are directed to conduct the learning phases of the ILL model. The two phases determine students whether they have knowledge of topic sentences, sentences, and supporting sentences in a complete paragraph. Linguistically, both phases encourage students to understand the paragraph attributes. It is in accordance with what Byram (2007) and Biebricher et al. (2019) state that cultural knowledge makes easier for language learners to perceive linguistic attributes of the target language.

The ILL model leads students to understand aspects of their own cultures and those of the target cultures. With having a broad knowledge of those cultures, students are easier to arrange sentences in writing and communicate with people. They can avoid misunderstanding of whole things 
spoken. In reflecting phase for example, students are directed to appreciate the diversities of cultural values among people in the world. These activities are aimed at reflecting what they have learned. According to Peng and Wu (2019), reflecting and respecting the intercultural transformation and cultural differences become critical indicators to predict communication patterns. In teaching writing, this knowledge points students to arrange their sentences into a paragraph. The problems faced mostly by students in writing class are difficult to express their thought in good arrangements because they have fewer ideas on what to write. In this study, the ILL model is able to help students to mitigate their writing difficulties.

When students construct their ideas into a complete text, a descriptive text, lecturers provide for them a graphic organizer of the descriptive text. They create a complete descriptive text based on the topic sentence, sentences, and supporting sentences that they produce in previous phases of the ILL model. In doing so, lecturers give them some the exercises how to write complete descriptive texts. The generic structures of the text, grammatical patterns, and vocabulary lists are presented. In addition, linguistic aspects are presented in the ILL model to assist students to produce a complete text of the descriptive text. To achieve the learning objective, students are divided into 34 members of each group. They share knowledge and skills in creating a complete introduction, body of text, and paragraph conclusion of the descriptive text. It leads students easier to create a complete text in this phase. This study informed that the intercultural competencies and sensitivities affected students' construction abilities of texts. It was contrast what Susilo (2019) found that intercultural sensitivity and exposure to foreign cultures are not significantly different.

The last phase of the developed ILL model is the presenting stage. After students complete a descriptive text, they are asked to present the resulted text in front of the class. Students share their text to other groups. They discuss all things relating to the content of their own cultural values and those of the target cultures reflected in their writing. They share about the organization of the text, grammar, language use, and mechanics. In this session, lecturers, of course, give feedback for students in line with the writing aspects assessed. The students' achievement writing skills improves. It is proved by the mean score of students taught by using the ILL model is 80.34 . The minimum classical grade is achieved.

\section{CONCLUSION}

After discussing the finding result of this study on how the effectiveness of the ILL model to teach writing skills, it can be concluded that there is a significant difference students' writing achievement between students who are subjected to the ILL model and those who are taught by using the conventional learning model. Considering this conclusion, first and foremost lecturers have to practice the ILL model to teach EFL because it makes the class more dynamic, possible to practice at all levels, and practical for ELT teachers or lecturers. 
Haerazi, \& Irawan, L.A. (2020). Developing Intercultural Language Learning (ILL) model to teach writing skills at Indonesian private universities. EduLite: Journal of English Education, Literature, and Culture, 5 (1), 43-54. DOI: http://dx.doi.org/10.30659/e.5.1. 43-54

\section{REFERENCES}

Alessio, D. D., \& Riley, M. (2002). Scaffolding writing skills for ESL students in an education class at a community college, 13(June), 79-89.

Aprianoto, Maurisa, S., \& Haerazi. (2018). Developing instructional tasks and materials of the intercultural-based English speaking skills (IBES) model, Journal of Arts, Science, \& Commerce, Vol. IX (October), 57-64. http://dx.doi.org/10.18843/rwjasc/v9i4/08.

Aprianoto, \& Haerazi (2019). Development and assessment of an interculturebased instrument model in the teaching of speaking skills. Universal Journal of Educational Research 7(12) pp. 2796-2805. DOI: https://doi.org/10.13189/ujer.2019.071230

Atay, D., Kurt, G., Camlibel, Z., Ersin, P., \& Kaslioglu, O. (2009). The role of intercultural competence in foreign language teaching. Inonu University Journal of the Faculty of Education, 10(3), 123-135. https://doi.org/10.11648/j.ijll.s.2014020601.12

Barg, W. R. \& Gall, M. D. (2003). Educational research. New York: Longman.

Berk, R. R. (2017). Comparison of writing anxiety and writing dispositions of sixth, seventh and eighth grade students, International Journal of interaction, 10(1), 237-254. https://doi.org/10.12973/iji.2017.10115a

Biebricher, C., East, M., Howard, J., \& Tolosa, C. (2019). Navigating intercultural language teaching in New Zealand classrooms. Cambridge Journal of Education, $\quad O(0), \quad 1-17$. https://doi.org/10.1080/0305764X.2019.1581137

Byram, M. (1997). Teaching and assessing intercultural communicative competence. UK: Clevedon Hall.

Byram, M., Gribkova, M., \& Starkey, H. (2002). Developing the intercultural dimension in language teaching: a practical introduction for teachers. Retrieved from http://www.coe.int/t/dg4/linguistic/source/guide_dimintercult_en.pdf

Corbet, J. (2003). An intercultural approach to English language teaching. Britain: Cromwell Press.

Dimitrov, N., Dawson, D. L., Olsen, K. C., \& Meadows, K. N. (2014). Developing the intercultural competence of graduate students. Canadian Journal of Higher Education, 44(3), 86-103. Retrieved from http://ojs.library.ubc.ca/index.php/cjhe/article/view/186040

Dimitrijević, A., Starčević, J., \& Jolić Marjanović, Z. (2019). Can ability emotional intelligence help explain intercultural effectiveness? Incremental validity and mediation effects of emotional vocabulary in predicting intercultural judgment. International Journal of Intercultural Relations, 69(2018), 102-109. https://doi.org/10.1016/j.ijintrel.2019.01.005

Farahian, M. (2017). Developing and validating a metacognitive writing questionnaire for EFL learners, Issues in Educational Research, 27(4), 


\section{6-750. http://www.iier.org.au/iier27/farahian.html}

Hadi, S., \& Andrian, D. (2018). Detecting teacher difficulties in implementing the local curriculum developed by the local government. New Educational Review, 53(3), 250-260. https://doi.org/10.15804/tner.2018.53.3.21

Haerazi, H., Irwansyah, D., Juanda, J., \& Azis, Y. A. (2018). Incorporating intercultural competences in developing English materials for writing classes. Journal of Language Teaching and Research, 9(3), 540-547. http://dx.doi.org/10.17507/jltr.0903.13

Haerazi, H., \& Irawan, L. A. (2019). Practicing genre-based language teaching model to improve students' achievement of writing skills. IJELTAL (Indonesian Journal of English Language Teaching and Applied Linguistics), 4(1), 9-18. http://dx.doi.org/10.21093/ijeltal.v4i1.246

Haerazi, H., May Vikasari, R., \& Prayati, Z. (2019). The use of scientific-based approach in ELT class to improve students' achievement and classroom interaction. Register Journal, 12(2), 157-180. https://doi.org/10.18326/rgt.v12i2.157-180

Hasani, A. (2016). Enhancing argumentative writing skill through contextual teaching and learning. Educational Research and Reviews, 11(16), 15731578. https://doi.org/10.5897/ERR2016.2806

Hoti, I. (2014). A Comparative view on English and Albanian language textbooks: The paper attempts to present a comparative view on English textbook and Albanian language.

Knap, P. \& Watkins, M. (2005). Genre, text, grammar: Technologies for teaching and assessing writing. Sydney: UNSW Press Book.

Lee, T. E. (2016). Re-writing and re-constructing British culture : a Case study on Chinese translations of a concise Chinese-English dictionary for lovers, International Journal of Language Learning, 4(1), 75-84. https://doi.org/10.15640/ijll.v4n1a9

Liddicoat, A. J. (2013). Language teaching and learning as an intercultural endeavor, Intercultural Language Teaching and Learning, (section 7), 4762. https://doi.org/10.1002/9781118482070.ch4

Liddicoat, A. J., \& Scarino, A. (2013). Assessing intercultural language learning. Intercultural Language Teaching and Learning, (July), 123-142. https://doi.org/10.1002/9781118482070.ch8

Lourenço, M., Andrade, A. I., \& Sá, S. (2018). Teachers' voices on language awareness in pre-primary and primary school settings: implications for teacher education. Language, Culture and Curriculum, 31(2), 113-127. https://doi.org/10.1080/07908318.2017.1415924

Murcia, M.C. (2007). Rethinking the role of communicative competence in language teaching. Journal of Intercultural Language Use and Language Learning, 41-57.

Mayhill, D. \& Watson, A. (2011). Teaching writing. In Andrew Green (Ed.). Becoming a reflective English teacher. Berkshire, England: Open 
Haerazi, \& Irawan, L.A. (2020). Developing Intercultural Language Learning (ILL) model to teach writing skills at Indonesian private universities. EduLite: Journal of English Education, Literature, and Culture, 5 (1), 43-54. DOI: http://dx.doi.org/10.30659/e.5.1. 43-54

\section{University}

Nunan, D. (2004). Task-based language teaching. Cambridge: Cambridge University Press.

Nurjanah, N., Suryadi, A., Abdulhaq, I., Hatimah, I., \& Budimansyah, D. (2019). Gender-sensitive effect of problem-based learning on student performance in Indonesian teacher college classes. New Educational Review, 55(1), 54-63. https://doi.org/10.15804/tner.2019.55.1.04

Peng, R. Z., \& Wu, W. P. (2019). Measuring communication patterns and intercultural transformation of international students in cross-cultural adaptation. International Journal of Intercultural Relations, 70(2018), 7888. https://doi.org/10.1016/j.ijintrel.2019.03.004

Pu, S., \& Evans, M. (2019). Critical thinking in the context of Chinese postgraduate students' thesis writing: A positioning theory perspective. Language, Culture and Curriculum, 32(1), 50-62. https://doi.org/10.1080/07908318.2018.1442473

Richards, J. C., \& Renandya, W. A. (2002). Methodology in language teaching: An anthology of current practice. New York: Cambridge University Press.

Sinaga, P., \& Feranie, S. (2017). Enhancing critical thinking skills and writing skills through the variation in non-traditional writing task, International Journal of Instruction, 10(2), 69-84. https://doi.org/10.12973/iji.2017.1025a

Susilo. (2019). Pre-service teachers' teaching skills, English proficiency, intercultural sensitivity, exposure to foreign culture across 12 environments. International Journal of Language Education, 1(1), 55-63. https://doi.org/10.26858/ijole.v1i1.6929

Sun, L. (2013). Culture teaching in foreign language teaching. Theory and Practice in Language Studies, 3(2), 371-375. https://doi.org/10.4304/tpls.3.2.371-375

UNESCO. (2013). Intercultural competences: Conceptual and operational framework. Paris: UNESCO.

Xue, J. (2014). Cultivating intercultural communication competence through culture teaching. Theory and Practice in Language Studies, 4(7), 14921498. https://doi.org/10.4304/tpls.4.7.1492-1498

Yu, L., Mei, Z., \& Qian, Y. (2014). Challenges in intercultural language education in China. Canadian Social Science, 10(6), 38. https://doi.org/10.3968/5426

Zhang, X. (2010). Developing Students' Intercultural Communication Competences in Western Etiquette Teaching. English Language Teaching, 3(4), 224-227.

Zhu, H. (2010). College English teaching viewed from the perspective of intercultural communication. English Language Teaching, 3(3), 107-110. Retrieved from http://search.ebscohost.com. 